\title{
Danish Immigrant Materials: The Archives at Grand View College
}

\author{
Thorvald HaNsen
}

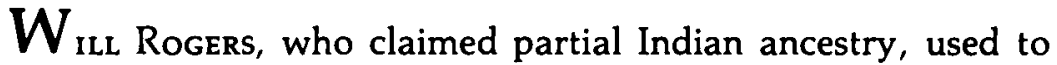
like to point out that his ancestors met the Mayflower at the dock. Be that as it may, it is certain that the dock was not crowded. The fact is, as John F. Kennedy once wrote, that this is a nation of immigrants. The vast majority of us are descendants of immigrants. Therefore, the history of this country, particularly at the grassroots level, is a story enacted by the immigrant.

This makes it important that we preserve and study the records of our immigrant ancestors. Fortunately, the growing interest in ethnicity in recent years has led to a greater emphasis on the preservation and use of immigrant archival materials. Grand View College in Des Moines has one of the best collections of archival materials in this country related to the Danish immigrant. Most of it is, unfortunately, buried in the Danish language, but there is a wealth of information here for those who are able to read Danish and who wish to study the immigrant Dane.

As might be expected, the archives, located on the second floor of the new library at East Fourteenth and Grandview Avenue, have long been a repository for information about the college itself. Indeed, here, too, may be found the records and other source materials related to Grand View's predecessor 


\section{The AnNals of lowa}

school, a short-lived theological seminary in northwestern Wisconsin. The information housed at Grand View is sufficiently complete that a comprehensive story of the seminary and the early years of the college has been constructed from primary sources.

Founded by the Danish Evangelical Lutheran Church in America in 1896, Grand View was for many years a predominantly Danish school. Thus, another dimension of the college archives is seen in its sizeable collection of Danish books. The nucleus of this collection has been augmented over the years to the point where it is now a rather good library of Danish literature, ranging from theological and literary works to those that would delight the historian and the biographer.

The centerpiece of the archival collection at Grand View is the material related to the life and times of the Danish immigrant in America. The college materials are, of course, a part of the immigrant's story, but that story ranges far beyond Des Moines and educational emphases. It is the story of a relatively small immigrant group, the bulk of whose members came between 1850 and 1920, and who were as diverse in settlement, occupations, and interests as they were in social background and dialect.

A significant part of his story is found in the immigrant's own writings. Danish immigrants, particularly those who became pastors, were prolific writers. Devotional books, sermons, novels, short stories, poetry, memorial booklets, pamphlets and other materials on a wide range of subjects issued from their pens. This points to the further fact that, by and large, the immigrants were voracious readers. A surprising amount of material was published, often (perhaps usually) at the writer's own expense. This could hardly have been done had not others been anxious to buy and read these things. In any case, most of this material is now permanently housed in the archives at Grand View.

Other primary sources of information about the social and cultural life of the immigrants are the Danish weekly newspapers and other periodicals which they published and read. Some of these papers and magazines are to be noted particularly for the polemical articles which shed a great deal of light on 


\section{The Grand View College Archives}

what took place. So, for example, one cannot fully understand the developments in the Danish Lutheran Church in America without studying the polemics which often preceded a particular action.

Among Danish weekly newspapers, Dannevirke (Breastwork of the Danes) is especially important. This privately owned, secular weekly, was begun at Elk Horn in 1880 . Shortly thereafter it was moved to Cedar Falls, where it continued until its demise in 1951. The run of this paper deposited at Grand View is virtually complete. Here may be found not only news from this country and from Denmark, but reports, stories and poetry, a wealth of articles of all kinds, as well as a great deal of advertising. Reference to Dannevirke is essential to an appreciation and understanding of that faction of Danes who founded Grand View College. The bound volumes of the paper held at Grand View are in poor physical condition and, like all old newspapers, very fragile. However, the danger of ultimate loss of the paper is minimized by its having been microfilmed for the Lutheran Church in America archives in Chicago. The difficulties in working with Dannevirke are compounded by the fact that, until 1914, Gothic type was used in the printing.

Following a merger with other Lutherans in 1962, the records of the old Danish Church became a part of the archives of the newly formed Lutheran Church in America. Many of those records, however, exist in duplicate and these are housed in Des Moines. Thus, from its founding in 1872 to the schism in 1894, through the name change in 1954 and, finally, to the merger in 1962, the story of the Danish Church in America may be traced in detail at the Grand View archives. Reports, minutes of meetings, church papers, records of many kinds, polemical articles, and an abundance of pictures are but some of the items that make up the Des Moines collection.

In connection with the history of the church, the holdings offer a large collection of congregational anniversary publications. In a growing number of cases these booklets mark centennial observances. In others they mark seventy-fifth, fiftieth, or twenty-fifth anniversaries. There are numerous cases in which 
we have publications issued by the same congregation for more than one of its observances.

Another important resource for the study of Danish immigrant behavior is the system of files maintained on individual immigrants. The sole criterion for establishing such a file is the possession of some bit of information concerning the person which is not cataloged in any other way. Into such files go clippings, letters, obituaries, and any other pertinent information concerning that individual. The contents of such files, as well as their number, is expanded whenever new information becomes available to us.

Among the items often included in such files are memoirs or personal histories. Quite a number of immigrants have written such histories, telling the story of why and how they left the old world and how they set down roots in the new. Few of these have been published. Some exist only in longhand, while more have found their way into typescript. The writers generally have been motivated by a desire to make the story of their background available to their children and especially their grandchildren. As might be expected, therefore, quite a number of these have either been written in or translated into English. These "short and simple annals" frequently present an invaluable "closeup" of the immigrant. A similar system of files is maintained for Danish organizations and Danish communities. Whenever applicable, cross-indexing is employed making it possible to quickly locate any filed item.

Some of the Danes who came to these shores were especially devoted to a particular kind of educational institution which arose in nineteenth century Denmark and which was known as the folk school. As a consequence, they lost no time in attempting to transplant the folk school to America. The first such school was begun at Elk Horn in 1878. The last attempt was in Canada in 1920. At various times between those two dates, five other folk schools functioned. Four of these were in the Midwest, while one was in California. Some flourished for a number of years; others lasted but a short time. Together they contribute an important chapter to Danish immigrant history. The archives at Grand View can boast the largest amount of extant information regarding these schools. Indeed, for his recently 


\section{The Grand View College Archieves}

published book, Schools For Life, which deals with the folk school in America, the author, Enok Mortensen, relied heavily on the material in the Grand View archives.

To date we have almost no oral history. Taping interviews is, of course, a relatively new procedure, and thus far we have lacked the means to conduct this kind of historical research. However, as more and more tapes become available, we look forward to adding them to our collection.

If we lack tapes we do not, on the other hand, lack photographs. We are in possession of a large number of pictures of all kinds. A rather high percentage of these are identified. The process of attempting to identify the others continues, but those that cannot ultimately be identified must be considered worthless.

The number of volumes in the English language dealing with immigrant history is not large, but it is slowly growing. Little by little the immigrant's story is being made available to his American descendants. Little is to be found in the area of translation, aside from songs and hymns. Translators have been busy for years and are still working to make the immigrant's heritage in song known to his English-speaking progeny. The archives holds an abundance of books in which the original songs and hymns may be found, and the number of translations is increasing.

Very few artifacts are to be found at Grand View. This is not because we are uninterested in such but because we lack both the space and the staff to do justice to a collection of museum pieces. These are not actively solicited, therefore, but they are accepted in the hope that there will one day be a Danish immigrant museum in this country.

It should be pointed out that the materials held at Grand View are from all sections of this country. One characteristic of Danish immigration is that it was widely scattered. Many Danes did settle in communities and organize churches, but many more went their own way and were, as a result, more or less lost in the process of assimilation. For this reason, archival materials related to the Danish immigrant may be found, sometimes in the most unlikely places, here and there throughout the coun- 


\section{The Annals of Iowa}

try. An awareness of this fact has led to a joint effort by the college and the Danish American Heritage Society to locate such materials. A project called Danish Immigrant Archival Listing has recently been undertaken. Its aim is to locate, catalog, and eventually list all Danish immigrant archival material found in the United States, Canada, and Denmark. The completion of this ambitious project is hardly in sight and, of course, we have no expectation of being able to locate every item. The project has progressed successfully to date, however, and much information has been uncovered. It is hoped that the project will help future scholars and researchers more readily know what materials are extant and where they may be located.

Meanwhile, the archives at Grand View College continues to be one of the best repositories of primary sources related to the Danish immigrant. The sorting, identifying, and cataloging of the collection is by no means complete, but the work continues and, as it does, the immigrant story grows in detail and clarity.

\section{Sfolen i Deg Moilte?.}

Dent baulfe coang.: luth. Rirfes Sfole $i$ Des Moites, Solva, mootager Glever bell 26be September og holber Ilabuingsmpbe bell 2rbe Sept.

5jiteraarsterminen begynber belt 28 . Sept., og varer til bell 28be Toventber.

I ball hojere farllesffole vil ber bline givet Ulubervisunitg i iqlgenbe frag: Religion, $\mathfrak{L a}$ : tit, Engelif, Tyff, Danff, Siijtorie, Tatur: Gijtorie, Taturlcere, Matematil, Jyjiologi, Beografi, Sfribuing, Reguing og Sang.

Ecritilt llnbervisning vil bline givet jor Ecrerc og Earerinber $i$ bell baulte og bault: cugelffe Bprneffole, bl. a. i Mieligion og $\mathfrak{B}_{\alpha}=$ bagogif, og jor bem, ber julfer at bugtig= gore fig til forretuingslivet, i Bogiøring m. m. For enfelte jaga Bebtommenbe vil Ulıbervis̈uingen blive leber $i$ bet engelffe Gprog.

Dezubent vil ber blive Golbt forebrag over firfelige, hiftorifte og vibenifabulige (5muer.

Angaaenbe ben theologifte Aibeling veb Stolen vil ber blive givet næermere DRebbelelfe lige efter 2arకెmøbet.

Retaling for Unbervisuing, Sopt og Bolig 15 Dofl. om Maaneben.

Jilbmelbelfer mobtages og Foreipdigaler bejuares af

Nev. \&. P. Grabengaarb, Braytori, Joma.

Notice of the opening of Grand View

College on September 26, 1896 (appeared in the Danish church paper, Kirkelig Samler). 
Copyright of Annals of Iowa is the property of State of Iowa, by \& through the State Historical Society of Iowa and its content may not be copied or emailed to multiple sites or posted to a listserv without the copyright holder's express written permission. However, users may print, download, or email articles for individual use. 